\title{
Erratum
}

\section{Calymenid trilobites from the Wenlock Series (Silurian) of Britain}

\section{Derek J. Siveter}

Transactions of the Royal Society of Edinburgh: Earth Sciences, 86, 257-285, 1996.

The publishers apologise for an error in the legend to Table 1 (p. 257) which could lead to misunderstanding. The correct legend and table are printed below.

Table 1 Occurrence of calymenids in the Wenlock Series of Britain (based on Siveter 1980, 1983, 1985 and data cited hesein) and Silurian outcrop elsewhere. + Definite occurrence; $+(?)$ some doubt as to precise age; $+(? ?)$ much doubt as to age; and $(+)$ definite occurrence of the nominate species to which the British material put under open nomenclature is compared. The position of the plus signs within the Wenlock Series, Britain, indicates the relative stratigraphic position within that series.

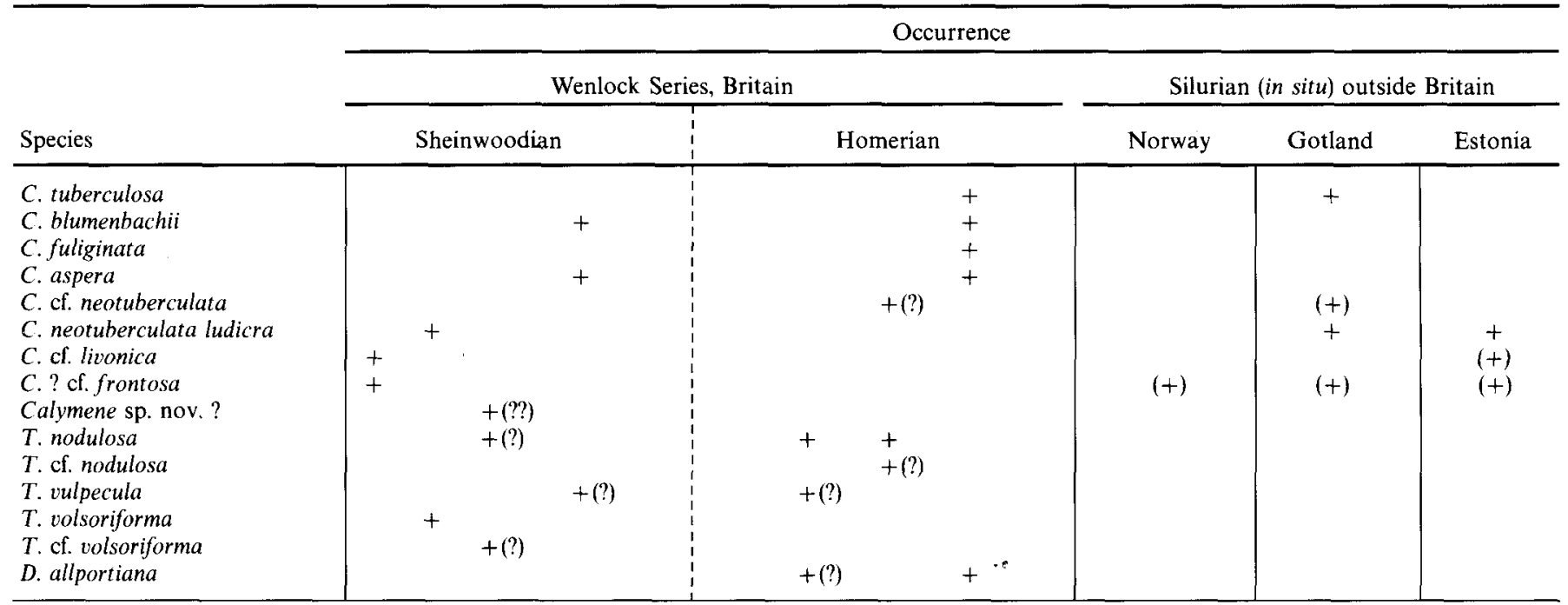

